\title{
Urban Housing in Mainland China: A New Chapter
}

Dr Andrew Marshall Hamer, Department of Real Estate and Construction, The University of Hong Kong

And

Miss Ester van Steekelenburg, Department of Real Estate and Construction, The University of Hong Kong

\section{A. Introduction and Objectives}

This paper sets out a modest agenda. It briefly reviews the Mainland's urban housing initiatives to date. It then questions whether these form part of a coherent and comprehensive housing strategy. While focusing on issues rather than data; it ends by stressing that planning without adequate facts is problematic. In sum, the spotlight is on questions that need yet to be answered; rather than the more ambitious task of prescribing a precise blueprint for simultaneously resolving all the issues at hand.

Though the piece is, by nature, a critical look at housing policy formulation, it must be acknowledged that the Mainland has managed, over the last two decades, a prodigious building record that provides an average household with as much housing as in the far more prosperous Hong Kong SAR ${ }^{1}$. And the slums of the developing world cities are largely unseen in Mainland urban areas. China's housing policy makers therefore have much to be proud of and nothing mentioned herein should be seen as attempting to detract from that.

\section{B. Context : The Evolving Nature of Urban China Housing Policy}

The purpose of this section is to briefly review urban housing policy in China, thus placing the new State Council (Cabinet) Circular \#23 (July 1998) ${ }^{2}$ in context.

For reasons largely associated with early decisions made after Liberation in 1949- to rapidly strengthen China's urban industrial capacity under expanded Government supervision and financing - urban housing became the responsibility of the "work unit". Low wages were offset by the availability of cheap rental housing, social security protection, and low cost rationed commodities. As early as 1980, Senior Leader Deng Xiaoping opened a debate

1 The average living space per resident in Chinese cities has increased from $3.9 \mathrm{~m}^{2}$ in 1980 to $8.5 \mathrm{~m}^{2}$ in 1996. (China Economic Yearbook, 1997 in: Liu, 1998). Average public housing living space in Hong Kong SAR is $8.3 \mathrm{~m}^{2}$ (Hong Kong Housing Authority 1997).

2 The text was made available to the authors by the Ministry of Construction. Also see Beijing Real Estate, 1998. 
on reforming the housing delivery system. Though many local experiments were carried out, comprehensive central directives have been issued only four times: in 1988, 1991, 1994 and 1998. Though there are variations among these, and new layers of detail have appeared over time, there is a rough consistency in the message delivered by the first three reform plays. The main direction of China's housing reform prior to 1998 can de described as follows ${ }^{3}$ :

- Work unit housing rents should be increased over time.

- However, a consensus emerged that rent reform could not be accompanied by systematic wage reform. In other words, in kind benefits would not be directly cashed out. Any rent reform would have to proceed at a very gradual pace.

- The long-term financing of rental housing run by independent institutions charging cost-recovery rents (with or without government subsidies) was therefore never seriously considered.

- As a result, homeownership schemes - the sale of work unit housing to sitting tenants - were viewed as a key way to raise funds to build more work unit housing; even sales at high discounts would bring in money more rapidly than gradually increasing rents. One could characterize Government policy as one of eventually abandoning rental housing solutions.

- Borrowing selectively from Singapore, Government came up with local Public Accumulation Fund schemes; work units and workers would each contribute to a Fund whose essential purpose was to promote home buying in the face of low rents. It would take an unnecessary detour to explain the multi-faceted aspects of this scheme. The funds could be left untouched and claimed upon retirement; but low interest payments for such funds provided little incentive for consumers to wait very long to claim use of the funds.

- $\quad$ The Fund, through the China Construction Bank (acting on an agency basis) would make mortgages available to home buyers, up to $70 \%$ of the value of a unit, with limits placed on the maximum size of loans; if sufficient demand failed to materialize, the Fund's resources would be made available to developers in the form of construction finance.

3 See World Bank 1992, Hamer 1995 and Hamer 1997. Other studies include Chen, 1996; Chiu, 1996a and b; Lau, 1994; Lee, 1995; Li \&Tang 1997; Shen \& Yu, 1996; Wang, 1995; Wong et al, 1998; and $\mathrm{Wu}, 1996$ a and b. For a more detailed description of the history of China's housing reform, see: Wang \& Murie, 1996 and Zhou \& Logan, 1996.

The reform has other dimensions, notably the creation (after 1984) of a vigorous for profit set of real estate development companies. They account for most urban housing construction in China today. For the purposes of this paper, this reform is not believed to affect the key elements of the housing debate described below. 
- Gradually, all banks were encouraged to manage Public Accumulation Fund accounts, and lend to home buyers, supplementing the Fund loans, which have always had rather conservative upper limits. ${ }^{4}$

- Housing finance proceeded to advance in a rather curious environment; most notably, no one talked much about collateral and mortgages became essentially signature loans. This suggests that key elements of the property rights' and obligations' agenda remained to be addressed. ${ }^{5}$

- Selling off housing to sitting tenants was the main vehicle of homeownership promotion; however, various pilot schemes to supply new housing emerged requiring subsidies from local governments and developers. These were generically referred to as Anju Housing, and were targetted at households whose per capita residential space fell below half the national urban standards.

- Being fully aware that buyers of subsidized housing would be tempted to resell at market prices, various restrictions were introduced as to when and how such resales could take place; again the issue of property rights reemerged as a question.

- At some risk of simplification, one can state that earlier housing policy had no explicit poverty focus; after all, the poorer rural majority did without government help, why should the urban poor expect more than the traditional low rent, work unit housing delivery deal?

\section{The 1998 Initiatives and Overall Housing Reform}

While there are common threads that run across the four circulars, there are also some features of the 1998 plan that appear to mark a departure from the past. Among these, five bear underlining as significant changes:

- Welfare rental housing allocation through work unit provision is supposed to cease, as far as new housing is concerned.

- New efforts will be made to accelerate rent reform, while still promoting homeownership as a top priority.

$4 \quad$ Until 1997, the China Construction Bank was the only bank authorized to provide mortgages nationwide. As of October 1998, the China Construction Bank had outstanding loans totalling $¥ 37.8$ billion; for 1998 alone, the total will exceed up $¥ 17.3$ billion. Among the outstanding loans, $¥ 20.4$ billion were commercial loans granted to 565,000 borrowers; and $¥ 17.4$ billion were policy loans, with 936,000 borrowers. In 1998 alone, commercial loans totalling about $¥ 10$ billion were issued to 188,000 borrowers; another 226,000 borrowers took out policy loans amounting to $¥ 7.3$ billion. The amount of "double-borrowing" from funds and banks is unclear.. For any given loan term, typically 10 years or less, policy loans are 40 percent cheaper than commercial loans.

5 Banks do have the option to take the purchased property as collateral, and undertake repossession after six months of non-payment, but eviction is problematic and resale values very uncertain. Banks also have the option to accept other assets as collateral. 
- Subsidized homeownership schemes will now be broadened to cover the bulk of the urban population;

- The principle that work unit funds previously consumed in buying or building welfare housing may be turned into worker housing allowances is now accepted; this represents a major conceptual advance, though, in practice, it has some very restrictive features, discussed below.

- The poorest of the poor are now acknowledged as deserving special Government attention.

Yet, ominously, the reform's implementation has been allowed to slip into the future and, as before, localities remain responsible for adapting the reform to local conditions, making implementation monitoring all the more difficult. It is too early to say if pessimists or optimists will prevail in their judgement of where this process will end. What is disconcerting is that the latest circular seems disconnected from the overall process of system reform in at least four respects:

- It fails to acknowledge the complex interaction of housing and overall reform.

- It fails to recognise that additional institutional arrangements are sorely needed for a housing reform to succeed.

- The housing allowance scheme is deeply flawed.

- Linked to that latter point, the circular reflects an inadequate review of international experience.

Taking these points individually, housing reform is occurring at a time of increasing insecurity among urban workers as to their future employment and income possibilities. Long-term investments in home ownership may not normally loom large as priorities for such households.

Yet the macroeconomic agenda is clear : the work unit has to get out of the housing business. State-owned enterprises are shedding workers and face pressure to focus on core business functions and to cut costs. The reasons are numerous : domestic overcapacity in many industries, export pessimism brought on by the Asia Crisis, and the increasing probability that international political considerations will ease import access to China's markets ${ }^{6}$. At the same time, the non-state sector, including purely private businesses, is now the source of virtually all new urban employment. ${ }^{7}$ It has no historical commitment to providing welfare benefits for its employees. If anything, one could cynically

$6 \quad$ For a more detailed description see World Bank 1995, 1997a and 1997b.

7 See World Bank 1997b. 
conclude that it thrives by taking advantage of a "one family-two systems" policy : one family member remains in the state sector to ensure the usual welfare benefits flow to the household, while others move over to the non-state sector. This is a prescription for disaster because it brings with it the sure promise of an ever increasing number of loss-making enterprises crowding into a public sector enterprise hospital! Something has to change.

Then, there are the rural-to-urban migrants, who are conventionally assumed to account for 20-25 percent of the urban work force ${ }^{8}$ and still increasing in size; Their welfare needs are conspicuously absent from housing policy statements. Their housing requirements must be met; yet they have been ignored in the past and at present.

The housing allowance component of the new reform package is not at all as radical and comprehensive as it might seem on initial examination. It is theoretically available only to workers whose households have no independent housing unit or to workers whose housing space standards are below locallyestablished norms. In the first instance, workers can hope to receive "vouchers" that close the gap between the cost of "Economic and Affordable Housing" (a subsidized scheme somewhat similar to the earlier Anju Housing) and four times the household's annual income. In the second instance, workers "vouchers" are further restricted to cover only the self-same gap involving the additional housing space needed to reach the locally-established norms. Even then, both categories of workers can only depend on the voluntary agreement of their employers. If the employers refuse to participate, the eligible workers will receive nothing.

More than issues of equity are involved. As discussed below, "Economic and Affordable Housing" is not likely to be much cheaper than commercial housing, once location and unit characteristics are taken into account. Without a more generous wage reform; or further supply side measures to reduce costs; there may be far less demand for housing on the part of individuals than is implicitly assumed by Government. When SOEs are forced out of the market for new housing, overall demand may fall sharply. Admittedly, the issue is, at this stage, hypothetical. But the problem bears urgent examination by the Chinese authorities. ${ }^{9}$

Some would object any enterprise-wide system of housing allowances is unaffordable. For loss-making enterprises this is obviously the case; such entities need to be reorganized, merged, or declared bankrupt. The lack of any housing allowances implies there is no current program of housing development or that any such program is unsustainable; it also emphasizes the fact the enterprise is uncompetitive and unattractive to job seekers in the labor market. Profitable enterprises can be assumed to have substantial housing development programs. The authors assume, as a worthwhile hypothesis, that a credible

8 Chan 1994 gives the necessary background for this story. See also World Bank $1997 \mathrm{~b}$.

9 Work units account for about 50 percent of annual new housing demand, across urban areas of all sizes. Source : Ministry of Construction. 
housing allowance program would cost enterprises less than the massive provision of in-kind benefits. This has been clearly demonstrated by the World Bank housing project (World Bank, 1994). The hypothesis needs to be tested in a wider context.

The next point merges into the fourth: China's urban housing reform still has no independent rental housing institutions on the planning horizon, in spite of the fact that almost every major developed country city has a substantial rental sector detached from work units. International experience tells us households want tenure choices; many and often most urban households don't want to own a housing unit ${ }^{10}$ !

Furthermore, international experience tells us it is common practice for governments to have supply-side and/or demand-side subsidy programs to deal with affordability issues faced by that proportion of a population whose average incomes are not large ${ }^{11}$. This, in turn, raises issues of who pays for what subsidies; ${ }^{12}$ who is deemed eligible for subsidies; and what institutional arrangements are set in place to deal with this issue. Finally, in developed country housing markets rental mortgages are available, allowing housing associations to bridge the gap between lumpy building acquisition costs and the annual flow of rental income. ${ }^{13}$

Though much more detailed research is needed on the issue, it appears that the pilot subsidized Anju programs to promote homeownership have failed to achieve a key objective: to address the affordability issue, while developing a sustainable burden-sharing formula. The relatively low volume of local supply

10 Home ownership rates studies suggest there is an even balance between home ownership and rental housing in most European and North American countries. Home ownership rates vary from $65 \%$ in UK to $40 \%$ in Germany. Rental housing is considered an acceptable alternative for ownership housing especially in urban areas. In most European cities the housing stock in urban areas is dominated by rental housing.(Doling, 1997). Across Europe, even when rural households are included, rental housing remains substantial; within the rental sector, "social” or subsidized housing plays an important role.

11 Supply side measures include free or discounted provision of land and construction subsidies and bank loan guarantees. Demand side subsidies could take the form of individual rental allowances or tax relief measures for home owners.

12 Both Anju housing and its successor, "Economic and Affordable Housing”, have similar subsidy schemes. The local government is expected to forego any revenues from land leases, but developers (and buyers) must bear the full costs of acquiring land from rural townships and compensating tenants displaced by redevelopment schemes. In addition, while "on-site" infrastructure cost are borne by the developer and the buyer, the costs of connecting a housing estate to citywide infrastructure networks are financed by the local government. Finally, any participating developer must accept limits on profit as a percentage of investment costs. In the case of Anju housing, this is set as 15 percent; in the case of "Economic and Affordable Housing" this is set at 3 percent. Since most developments are highly leveraged, with bank loans providing most financing, the return calculated as a percent of developer equity would be three or four times that rate. Government has authorized the building of 211 million $\mathrm{m}^{2}$ of "Economic and Affordable Housing”. 70 million $\mathrm{m}^{2}$ were completed in 1998. This compares with overall annual urban housing space targets of about 360 million $\mathrm{m}^{2}$. Data provide by Ministry of Construction.

13 For a description of European experience in this area, see Larkin and Lawson, 1998. 
is evidence enough that all is not well ${ }^{14}$. Worst still, there is scattered evidence that work units are often primary buyers of these units ${ }^{15}$ - bringing the reform process back around to where it started.

The Anju program has had a very limited objective : to help the "housing poor". Now the plan is to provide the new housing solutions for all "low and middle income" households (itself an awesome target group!). Many new questions arise. Perhaps much deeper subsidies are needed to make this homeownership option attractive in a prevailing low rent housing environment. Perhaps, as noted, macroeconomic conditions are not conducive to urban homeownership promotion. What is obvious is that the role of a mass program of "Economic and Affordable Housing”, as the key pillar of the urban housing policy, needs serious rethinking.

\section{Looking Beyond the 1998 Reform}

The debate over housing policy has to be widened further. Possible options now include acknowledging that abolition of welfare housing can be accompanied by a comprehensive wage reform as an offsetting form of compensation. To date the Public Accumulation Fund has been the main vehicle for a disguised form of wage reform - but its relative scale (5-6\% of wages each, from worker and employer ${ }^{16}$ ) is still small, given the added household cost to move to a nonwelfare housing system ${ }^{17}$. And if the Fund is to be the vehicle for income enhancement to be spent on housing, perhaps it is time to think the unthinkable - making funds available for all rental payments. ${ }^{18}$ Consideration may also be

14 Anju housing production only accounts for $7-8 \%$ of the annual housing production in Chinese cities, See Liu, 1998. This is confirmed by sources interviewed during fieldwork carried out in Beijing, Shanghai, Tianjin and Guangzhou.

15 Research indicates that work units represent $80 \%$ of the Anju buyers. They subsequently sell it to their employees at a discounted price, transforming it into a welfare good. See Wu, 1995 \& 1996; Liu 1998; Chiu, 1996\&1997; and fieldwork cited in the previous footnote.

16 Shanghai set up the first Housing Provident Fund in the country. Now all major cities have a Provident Fund. The percentage of the monthly salary that is contributed to the Provident Fund varies depending upon location and upon the type of employer. (i.e. a state owned or joint venture company). In most cities the contribution is around 6\% of the worker's monthly income, but there is evidence of cities charging substantially higher amounts ... up to $11 \%$ (Shangdong and Shaanxi Provinces). In Shanghai, the cradle of the Provident Fund, there are plans are to increase the percentage annually so that in the year 2000 all participating employees and employers each pay 10\%. Figures were supplied by the Provident Fund Management Centers in Shanghai, Beijing and Tianjin.

17 Prices of Anju housing in China’s major cities vary from $1.500-2.800 ¥ / \mathrm{m}^{2}$ depending on location. Individual buyers may pay less; the difference is absorbed by the work unit. Comparably located commodity, or unsubsidized, housing is 10-25 percent higher in price. Rental levels for 'work unit housing’ were as low as $0.13 ¥ / \mathrm{m}^{2}$ from 1978 -1988 but have gone up in recent years. Again the level differs depending on location, but present rents in Shanghai range from 0.75-2 $¥ / \mathrm{m}^{2}$ while the range in Beijing is from $0.55-1.3 ¥ / \mathrm{m}^{2}$. Typically urban household incomes average less than $¥ 20.000$; though there are variations across cities. Figures were supplied to the authors by the Urban Housing Research Institute of the Ministry of Construction and confirmed in interviews carried out during fieldwork as mentioned in footnote 12.

18 At present, Fund accounts can be used to finance rents that exceed 15 percent of household 
given to introducing, on a selective and very targeted basis, housing allowances for the genuinely poor. Here, as elsewhere, there is international experience to draw upon ${ }^{19}$.

Independent social housing corporations need to be established, under government supervision, to build rental housing ${ }^{20}$. Supply-side subsidies could come in various forms - free land grants, construction subsidies, loan guarantees and tax exemptions. One tax measure worth considering is that of prorating the one-time infrastructure fees developers must pay; so that payments become more akin to the annual property taxes paid by all building owners in developed countries $^{21}$. Such housing might be made available to both poor and moderate income households alike, if the poor can count on some system of housing allowances to enhance their ability to pay.

Next, work unit housing could be divested from the enterprises and serve as initial investment for independent housing management companies. Workers would benefit from a wage reform allowing them to pay higher rents. The companies would charge cost-recovery rents and finance their housing stock expansion by drawing on long-term bank mortgage loans. Their rental income flow would act as collateral for long-term mortgages. On a pilot basis, in Beijing, Chengdu, Ningbo, and Yantai, more than one million workers and their households are already participating in such a reform program, under a World Bank project initiated in 1994. Such companies can, over time, move away from catering to the needs of their investor employees and service the general market $^{22}$.

In the case of loss-making and bankrupt work units, housing management companies would require government equity investments to make any such scheme viable. The issue of selective housing allowances for tenants would again be an issue. In fact these housing management companies would resemble the independent social housing companies cited earlier.

As far as homeownership promotion is concerned, one objective should be to promote the creation of a substantial pool of households with the means to buy unsubsidized housing. In this regard, an overly punitive, de facto capital gains

income; only the gap between actual rents and expected payments can be paid in this manner.

19 In most developed countries, governments have chosen not to leave housing to the market. There is always a safety net for the genuinely poor. For example, in Holland the government is providing rental units for poor people and special target groups with income difficulties such as immigrants, students and elderly people.(Doling, 1997; Papa, 1992).

20 Housing associations or corporations are a well known phenomenon in British and Dutch cities. In Holland housing associations manage $80 \%$ of the rental housing stock. The associations are private non-profit orientated organizations, which have the responsibility to provide housing for the weaker segments of society and are strongly subsidized by the government. (Doling, 1997; CBS, 1997).

21 In most European and North American countries property taxes are paid on an annual basis, the amount charged depends on the value of the property.

22 See Hamer, 1997. 
tax on the resale of subsidized apartments should be avoided, to the degree municipal revenue losses can be contained. ${ }^{23}$

All this having been said, why have more creative housing delivery solutions been ignored in China? There is no clear answer. Partly the problem lies in an inadequate study of international experience ${ }^{24}$. Partly the issue is one of bias against rental housing. Then, of course, there is the highly politicized issue of burden-sharing. Many would argue this last issue alone is enough to end the search for new solutions. But the point is that there has been no systematic effort to calculate the revenues and costs that such solutions would entail for the various participants. Until that is done, such alternatives should not be dismissed out of hand.

One more thing. Harsh as it may sound, a move to a more market-oriented system may force development of housing that is more economical because it produces units smaller in size than those recommended by the Ministry of Construction, and its associated local Construction Commissions, whose norms amount to proposing ever-larger unit size targets year by year. This too is part of the solution to the issue of burden sharing.

\section{E. The Role of Information in Developing Better Housing Policies}

Virtually any Mainland major city can list the number of new trees planted during the last year. None, to our knowledge, can provide detailed and accurate information on tenure choice : how many households live in rental public or work unit housing, how many rent private space; how many have bought work unit apartments previously occupied on a tenancy basis; how many live in the different types of built-for-sale apartments? ${ }^{25}$ Detailed annual supply data are also missing ${ }^{26}$.

23 At present great uncertainty exists as to what stance the national government will take in this regard. The only detailed guidelines are found in the 1994 Circular, according to sources at the Ministry of Construction. Housing originally sold at market prices can be resold without payment of capital gains taxes, other than a "land appreciation tax". Other taxes and fees, amounting to $20 \%$ of sales value, may apply. Units originally sold at "cost recovery prices” carry a subsidy element - primarily, the absence of any land lease payments. Sale conditions resemble those for commodity housing except that a land lease must be obtained. All housing sold at deeper subsidies carry only partial ownership rights. There is a five year ban on resale. Thereafter, the "original” co-owners (usually the work unit) have priority rights to buy the unit back at the original sale price. If the original co-owners have ceased to exist, the municipal government may exercise the right. Barring such resales, the unit can be placed on the market. Payment of land lease fees and applicable land appreciation taxes having been deducted, any gains are to be shared proportionately among the co-owners. The first test of this last category of sales will occur in 1999.

24 International experience has been studied in one area: financing homeownership. Among the models looked at are Germany's Bausparkassen; Holland's mortgage system that draws on insurance industry financing; and America's secondary mortgage market system. As noted, selective elements of Singapore's experience using a forced savings scheme (the Central Provident Fund) have been adopted by China's cities and renamed Public Accumulation Funds.

25 Press reports and local journals are the principal sources of information on this subject. Fieldwork also confirms widely differing estimates of relevant data. In Shanghai, for example, interviews with authoritative individuals working on housing reform suggest homeownership rates are as low 
The calculations needed to estimate ways to cut costs of housing (and how to pay for them) seem as scarce as studies on the use of selective housing allowance programs and the implementation of rent reform. The list could be endlessly extended.

The point is that good housing policy cannot operate in a statistical vacuum. Even if some of these data exist, they are simply not out in the public domain, so that analysts can then make informed judgements about present and future policies. This problem really must be tackled on a priority basis ${ }^{27}$.

\section{F. Conclusion}

Two decades into the reform of China's economic system, housing reform remains fragmentary and incomplete. No comprehensive blueprint has yet emerged, to be exposed to public scrutiny and debate. Housing reform still seems poorly coordinated with overall macroeconomic reform. The reasons appear obvious; it all boils down to who will pay for what, when overall resources are scare. Burden-sharing arrangements still need revisiting, as do the institutions associated with creating viable housing delivery systems. The one consolation for the student of Mainland urban housing is that they will still be in business for years to come.

as $25 \%$ or as high as 50 percent!

26 Supply figures are available in any statistical yearbook, however when the question comes down to categorizing housing types and development, even officials at the relevant departments could not give accurate figures but only make estimations on the exact supply of different housing types.

27 There are a number of journals published in China that are trying to fill that vacuum. The most important ones are :

- $\quad$ Beijing Real Estate

- $\quad$ China Real Estate Finance

- China Real Estate Information

- $\quad$ Chinese and Foreign Real Estate Times

- Housing and Real Estate

- Real Property Strategies

- Southern China Real Estate Journal

- Shanghai Real Estate Market

- Shanghai Housing

- China City Planning Review

- Urban and Rural Construction Development 


\section{References}

Much information has been gathered on numerous trips to Shanghai, Guangzhou, Ningbo, Beijing and Tianjin in 1997 and 1998. On these trips, interviews were held with government officials, private and public development companies, banks and academic experts in the field of housing and urban economic development. Special thanks are extended to the headquarters staff of the China Construction Bank, and to the Ministry of Construction.

\section{Other references include:}

Beijing Real Estate, 1998, State Council (Cabinet) Circular \#23, as published in Beijing Real Estate, No. 9, 39-42, Beijing, 1998.

CBS (Central Statistical Bureau), 1998, Jaarboek Wonen 1998, Facts and Figures of the Dutch Housing Market, Kluwer Publishers, 1998.

Chan 1994, Kam Win Chan, Cities With Invisible Walls: Reinterpreting Urbanization in Post 1949 China, Hong Kong, Oxford University Press, 1994.

Chen, 1996, Aimin Chen, “China's Urban Housing Reform: Price Rent Ratio and Market Equilibrium”, Urban Studies, Vol.33, No. 7, 1996.

Chiu, 1996, Rebecca Chiu, "Housing Affordability in Shenzhen Special Economic Zone: A Forerunner of China's Housing Reform”, Housing Studies, Vol. 11, No. 4. 1996.

Chiu, 1997, Rebecca Chiu, "Housing Reform in Shanghai \& Guangzhou; The Enduser's Perspective", Symposium on Marketization of Land and Housing in Socialist China, Hong Kong Baptist University, October 1997.

Doling, 1997, J. Doling, Comparative Housing Policy; Government and Housing in Industrialized Countries, The MacMillan Press, London, UK, 1997.

Hamer, 1995, Andrew Hamer, "Urban China, Looking Forward Looking Back”, in Anthony G. O. Yeh and C. K. Mak, eds, Chinese Cities and China's Development, Hong Kong, The University of Hong Kong, 1995.

Hamer, 1997, Andrew Hamer, “The Linkages Between State Owned Enterprise Reform, Expanding Urban Population and Urban Housing in China”, Symposium on Marketization of Land and Housing in Socialist China, Hong Kong Baptist University, October 1997.

Hao, Chen \&Sun, 1996, Shaoyi Hao, Yilin Chen \& Dahao Sun, A General Exposition of Property Management, Hai Tan Press House, 1996. (in Chinese)

Hong Kong Housing Authority 1997, Annual Report 1996/97, Hong Kong, 1997. Larkin and Lawson, 1998. Andrew Larkin and Julie Lawson, Financing 
Arrangements for Social Housing England, The Netherlands, Denmark and Germany, Sydney, National Community Housing Forum, February 1998.

Lau 1994, Kwokyu Lau, "Urban Housing Reform in China Amidst Property Boom Year”, China Review 1993, Hong Kong, 1994.

Lee, 1995, Peter N. S. Lee, "Housing Privatization with Chinese Characteristics", in Linda Wong \& Stewart Mac Pherson, eds, Social Change and Social Policy in Contemporary China, Hong Kong, Avebury, 1995.

Li, \& Tang, 1997, S. Li \&Y. Tang, "The Housing Market and Tenure Decisions in Chinese Cities”, Symposium on Marketization of Land and Housing in Socialist China, Hong Kong Baptist University, October 1997.

Liu, 1998, Hong Yu Liu, "Government and Intervention and the Performance of the Housing Sector in Urban China”, Journal of the Asian Real Estate Society, Vol. 1, No. 1, 1998.

Papa, 1992, Oscar Papa, Housing Systems in Europe: Part II a Comparative Study of Housing Finance, Delft University Press, 1992.

Shen, \& Yu, 1996, L.Y. Shen and X. Yu, "The Changing Process in the Chinese Urban Area Housing Reform”, Housing Science, Vol. 20, No. 1, 1996.

Wang, 1995, Ya Ping Wang, "Public Sector Housing in China; 1949-1988; The Case of Xian”, Housing Studies, Vol. 10, No. 1, 1995.

Wang \& Murie, 1996, Ya Ping Wang \& Alan Murie, "The Process of Commercialization of Urban Housing in China”, Urban Studies, Vol. 33, No. 6, 971989, 1996.

Wong et. al., 1998. Francis K W Wong, Stanley C W Yeung, Eddie C M Hui, Rodney Howes, and Lucy S P Kong, A Study of Welfare Housing Development in Major Cities of China. Department of Building and Real Estate, The Hong Kong Polytechnic University, September 1998.

World Bank, 1992, China: Implementation Options for Urban Housing Reform, Washington D.C., The World Bank, 1992.

World Bank, 1994. China : Enterprise Housing and Social Security Reform Project, Washington, D.C., The World Bank, Staff Appraisal Report, June 1994.

World Bank, 1995, China: Reform of State Owned Enterprises, Report No. 14924CHA, Washington D.C., The World Bank, 1995.

World Bank, 1997a, China's Management of Enterprises Assets: The State as Shareholder, Washington DC, The World Bank, 1997.

World Bank, 1997b, China 2020, Washington DC, The World Bank, 1997. 
Wu, 1995, Fulong Wu, "Urban Processes in the Face of China's Transition to a Socialist Economy”, Environment \& Planning, Vol. 13, 1995.

$\mathrm{Wu}$, 1996, Fulong Wu, "Changes in the Structure of Public Housing Provision in Urban China”, Urban Studies, Vol. 33 No. 9, 1996.

Zhou and Logan, 1996, M. Zhou and J.R. Logan, "Market Transition and the Commodification of Housing in Urban China”, International Journal of Urban \& Regional Research, Vol. 20, No. 2, 1996. 